\title{
Analysis and Development of Bina Nusantara University's BNPCHS School of Computer Science Competition Website Using the Laravel Framework
}

\author{
Dirga Sulinanda Putra ${ }^{\mathrm{a}}$, Goesdi Louis ${ }^{\mathrm{b}}$, Joshua Hidayat ${ }^{\mathrm{c}}$, Rhio Sutoyo ${ }^{\mathrm{d}}$ \\ a,b,c,d Computer Science Department, School of Computer Science, Bina Nusantara University, Jakarta, Indonesia 11480 \\ d rsutoyo@binus.edu
}

Article History: Received: 10 November 2020; Revised 12 January 2021 Accepted: 27 January 2021; Published online: 5 April 2021

\begin{abstract}
The purpose of this thesis is to facilitate the user to view the competition information, make the registration process and payment of the contest easily, facilitate the changing of content through the system, along with the data collection. In developing this website the methodology used is the method of collecting data through literature studies and interviews. While the design method used is the Waterfall method. The results of this thesis is a website that is implemented using a framework with a Content Management System (CMS). The conclusion of developing this website is to answer user needs for information, registration, and confirmation of competition payments
\end{abstract}

Keywords: Competition, content management system, laravel, website

\section{Introduction}

Every educational institution has various kinds of information that need to be informed and published. Various educational institutions namely schools, universities, high schools have details that need to be known and can be easily accessed by relevant parties in need. In this modern era, there are so many information media that can be used to convey the information needed. One of them is a website.

According to [1], information is data that has been organized so that it has meaning and value for the recipient. Then according to Sibero (2011), a website is a system related to documents used as a medium for displaying text, images, multimedia and others on the internet network. Nowadays, when the development of technology is so rapid, the dissemination of information is demanded to be faster and easier to access in all situations. Websites that are accessed through the internet that are almost affordable by all humans are relevant media for disseminating information.

Website media is also used by BINUS University to display information about everything needed for the public to know. One of the websites that BINUS University has created is a special website that contains information about a contest called Bina Nusantara Programming Contest for High School Students (BNPC-HS). BNPC-HS is a computer programming competition organized by BINUS University for high school/equivalent students in Indonesia. This website has content that contains everything that potential participants or parties need to know about this competition such as schedules, requirements, regulations, and other details.

\section{B. Problem Formulation}

1. Website is static, so content cannot be changed directly.

2. There is no direct registration system.

3. Payment systems that are still running now do not work through the system.

\section{Purpose and Benefits}

\section{The Purpose}

Develop a competition-based website that makes it easy for prospective participants to see information about the competition, register, make the payment process easier, and the admin can change content and confirm payment easily.

\section{The Benefits}

1. Users, in this case the contestants can see information clearly and make registration and payment processes easily through the system. 
2. Users, in this case the admin can change content directly without having to change the HTML script and confirm registration and payment through the system.

3. Facilitate the registration of data and registration of prospective participants so that each data is well managed.

\section{Research Methods}

\section{Analysis Method}

The research method used in this study includes two parts namely the Data Collection Method and the Design Method.

\section{Method of Collecting Data}

This method consists of 2 (two) stages, namely:

\section{Literature Study}

Look for references related to thesis preparation and related matters in it. Searches are carried out through the internet, e-books, thesis or other valid literature related to the program being made.

2. Interview

Interviews were conducted to find out application needs, shortcomings of previous applications, and matters relating to users and applications. Interviewees in this interview are those who will use this application both as admin and user.

\section{Design Method}

The method used is the Waterfall method. We use this method because this method has a sequential process, so a system can be developed as desired and right on target.

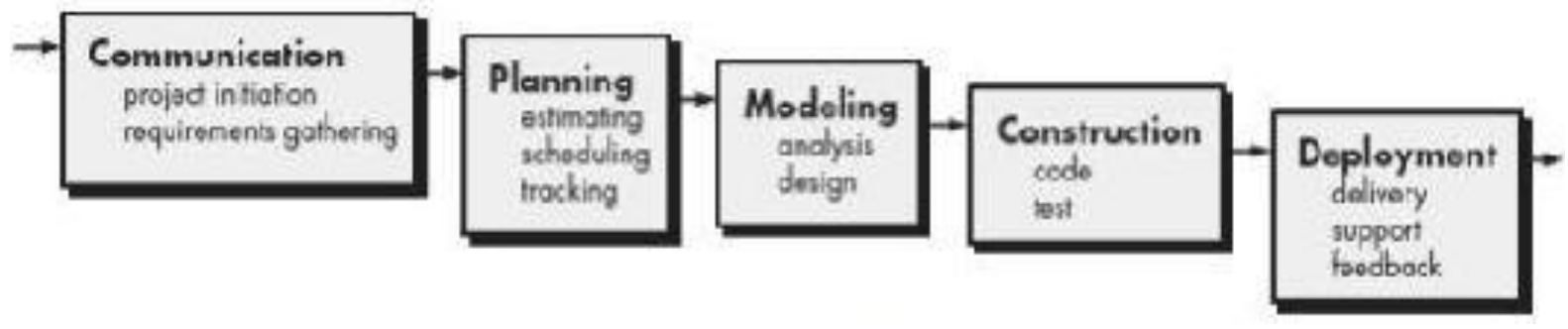

Fig. 1. Waterfall Stages

The several stages in the waterfall model are as follows:

-Communication

Analyze user needs with the aim of understanding project objectives and gathering user needs in order to be able to define software features that will be created along with their functionality.

- Planning

Define software manufacturing plans such as risks that may occur, resources needed, jobs to be carried out and work schedules.

- Modelling

Define user needs into a software design such as data structure design, software architecture, interface representation.

\section{- Construction}

The process of translating the design by the programmer in a language that can be recognized by the computer is adjusted to the needs that have been previously analyzed. Then do the testing stage on the system that has been made before in order to find and fix errors on the system.

- Deployment

The software that has been made is handed over to the user and then the evaluation phase is carried out and periodically maintains software 


\section{Research Methods}

The current system in the School of Computer Science competition, especially the BNPC-HS uses the website as an information center for participants who want to take part in the competition. Through interviews conducted with Mr. Rhio Sutoyo, S.Kom., M.Sc, information was obtained about the BINUS competition website that is currently active.

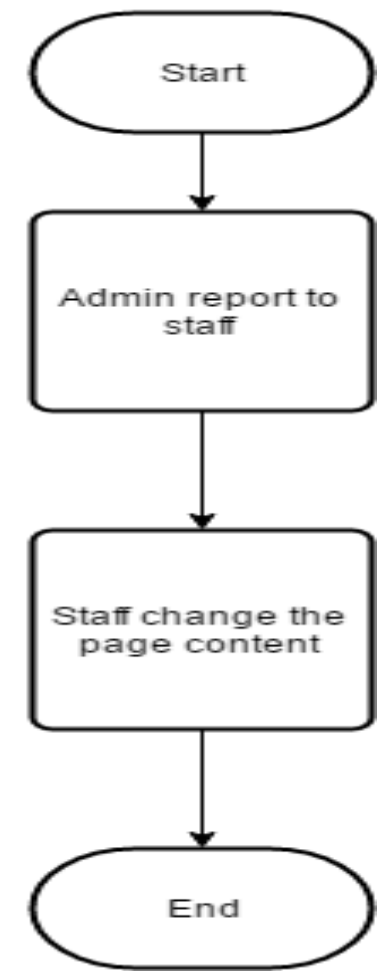

Fig. 2. Change the Old Content Flowchart

As can be seen in the flowchart, when there is content on the website that want to change, the admin must contact the authorized staff to replace the content by manually accessing the html file from the page.

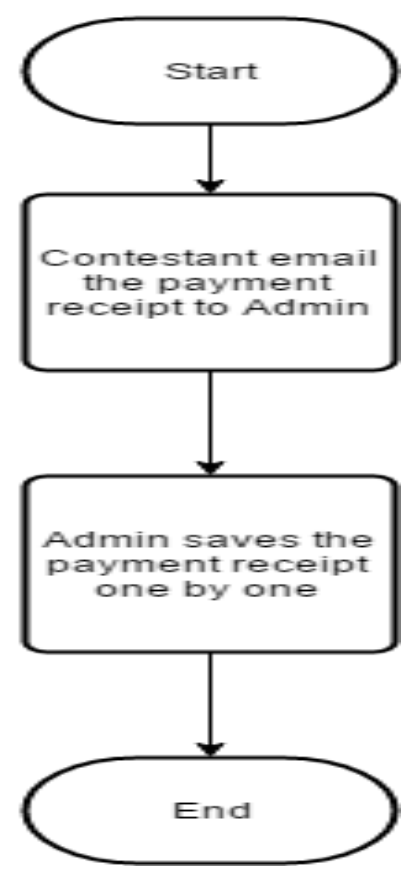

Fig. 3. Old Payment Confirmation Flowchart 
In addition, the payment confirmation system that is carried out is still using the manual method, for example, participants who have made the payment confirm by sending proof of payment to the admin via email. Then the admin will save the proof of payment and make a separate note.

\section{Results And Discussion}

At the School of Computer Science, Mr. Rhio Sutoyo, S.Kom., M.Sc as the Head of Computing Lab handles the competition, procurement and participation of contestants, research from lecturers and students, as well as collaboration with industry parties. In this matter relating to the development of the BNPCHS competition website, he stated the problem that occurred first was that the BNPCHS website was less attractive in terms of design and information. The annual competition, around 2010, is the same every year. The information provided is also monotonous. The website does not provide multimedia visuals such as photos, videos, documentation from last year.

The second problem that occurs is that the payment system from the BNPCHS website is still manually reported from the email. The person in charge of the registration section must manually save the e-mail and then sort it into proof of payment and send it to the financial authorities, even though the participant has registered via the website form. Reports are not automatically recorded by the system. The third is the split formation between beefest competitions such as ICPC, BNPCHS and others. Website appearance is not uniform.

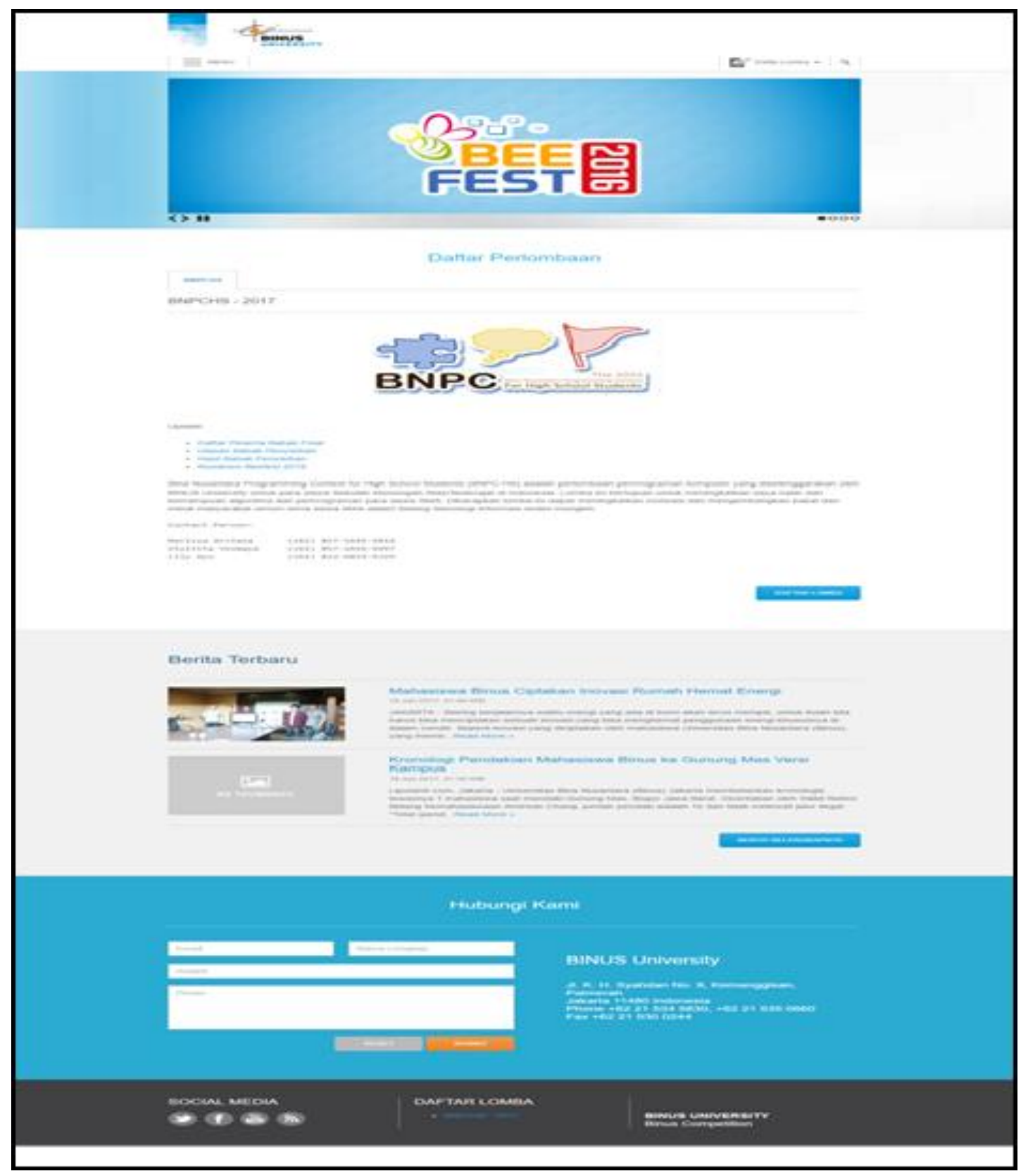

Fig. 4. Home Page 


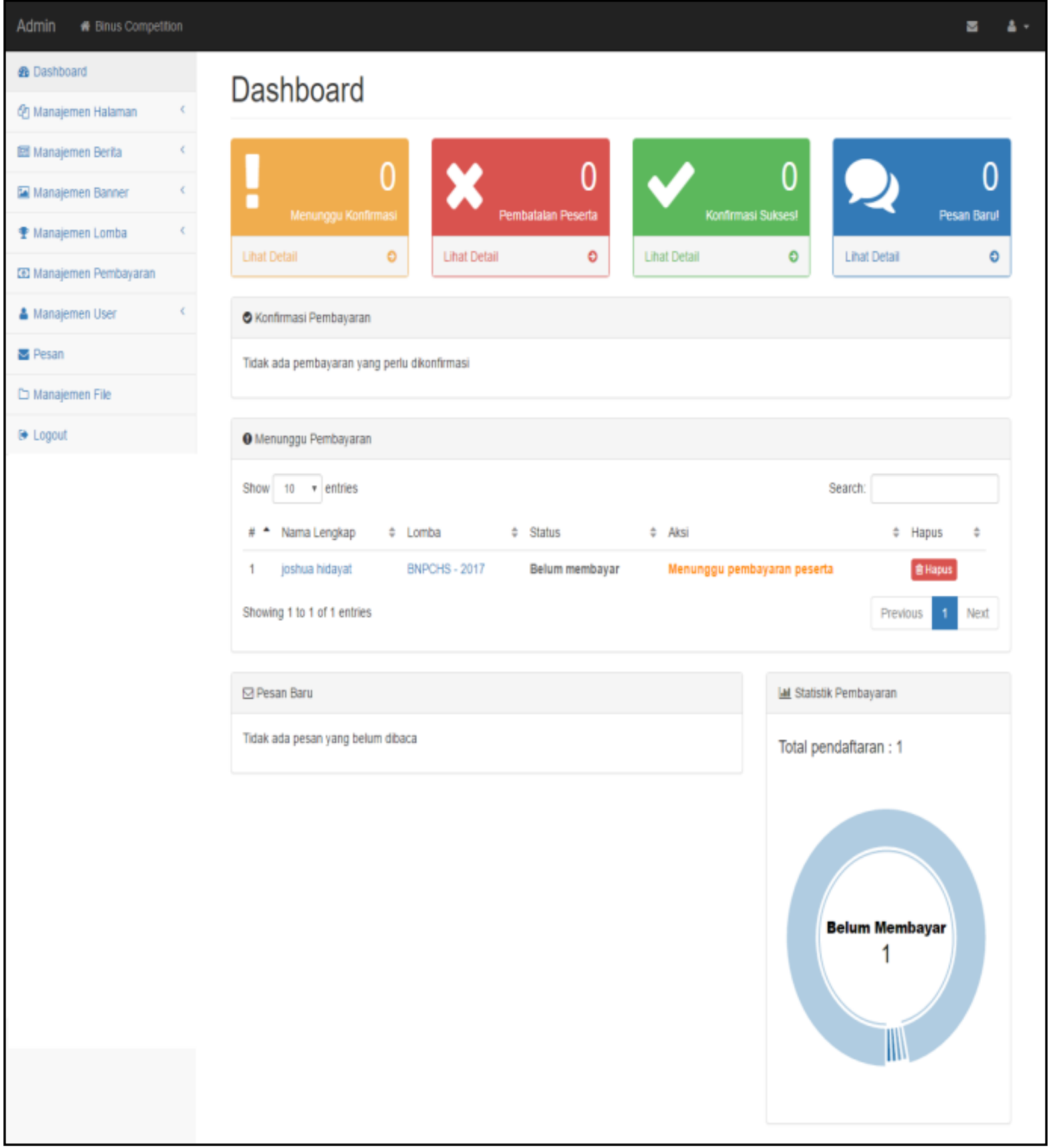

Fig. 5. Dashboard Page for PIC Role

\section{Conclusions}

From the evaluation of the School of Computer Science (SoCS) competition web application design, it can be concluded:

1. This application can make it easier for users to see information about the race clearly.

2. This application can make it easier for users to register and process payments easily through the system.

3. This application can facilitate the admin of the SoCS to change the content on the website.

4. This application can facilitate the admin of the SoCS to confirm payment through the system.

5. This application makes it easy for SoCS to collect data on registration and payment of prospective participants. 
From the discussion regarding the design of the School of Computer Science competition web application, there are some suggestions and input for this system: (1)Adds payment gateway features such as virtual accounts to facilitate the payment process; and (2) added a proof of payment check feature with mutations directly on the website to prevent counterfeiting of proof of payment.

\section{References}

V. Turban, E. \& Linda, Information Technology for Management, Edisi 7. Asia: John Willey \& Sons, 2010. Alexander F. K. Sibero (2011). Kitab Suci Web Programing. Yogyakarta: MediaKom.

Amarudin (2015). Cara Efektif Belajar Framework Laravel. Yogyakarta: Lokomedia.

Bruegge, B \& Duttoit, H. A (2010). Object-Oriented Software Engineering Using UML, Patterns, and Java. USA: Pearson.

Connolly, Thomas M., Carolyn E. Begg. (2015). Database Systems: a practical approach to design, implementation, and management. 6th Edition. America: Pearson Education

Duckett, Jon. (2010) Beginning HTML, XHTML, CSS, and JavaScript. Indianapolis: Wiley Publishing.

Janner, Simarmata (2010). Rekayasa Perangkat Lunak. Yogyakarta: Penerbit Andi

McFarland, D. S. (2011). JavaScript \& jQuery: The Missing Manual (2nd ed.). Sebastopol: O'Reilly Media.

Ninoriya, S (2011). CMS, LMS and LCMS for eLearning. International Journal of Computer Science Issues

Pressman, R.S. (2010). Software Engineering: A Practitioner's Approach (7th ed.). New York: McGraw-Hill.

Santosa, B. (2009) Pemanfaatan Content Management System (CMS) SIG Untuk Penyajian Data Hasil Pemilu. Yogyakarta: Semnasif UPN Veteran

Surendro, K. (2005) Pengembangan Learning Content Management System yang Mendukung Peningkatan Efektifitas Proses Belajar Jarak Jauh. Universitas Kristen Petra.

Shneiderman, B., \& Plaisant, C. (2010). Designing the User Interface: Strategies dor Effective Human-Computer Interaction (5th ed.). Addison-Wesley.

Sommerville, Ian (2011). Software Engineering (Rekayasa Perangkat Lunak). Jakarta: Erlangga.

Spurlock (2013). Bootstrap. (1st edition). Sebastopol: O'reilly Media.

Sulistiyono, Ratno Putro (2012). Website Development Using CMS. Bandung: Nuansa Cendekia

Welling, L., \& Thomson, L. (2009). PHP and MySQL Web Development (4th ed.). New York: Addison-Wesley.

Whitten, J.L. \& Bentley, L.D. (2007). System Analysis \& Design Methods: Seventh Edition. New York: Mc.Graw-Hill.. 